\title{
Спосіб життя родини як чинник ставлення підлітка до міського середовища
}

Анотація. У статті наводяться результати емпіричного дослідження впливу екологічно орієнтованого способу життя міської родини на ставлення підлітка до міського середовища. Встановлені прояви екологічно орієнтованого способу життя сім ї в мікро- $і$ макросередовищі міста. Ці прояви об 'єднує спрямованість сімейної життєдіяльності на повноцінне освоєння міських умов життя для задоволення всіх груп потреб особистості: фізичних, соиіальних, духовних. Доведено, щуо екологічно орієнтований спосіб життя родини сприяє формуванню ціннісного ставлення підлітка до міста та ідентифікації з ним.

Ключові слова: спосіб життя, екологія міста, психологія життєдіяльності, територіальна ідентичність.

Екологія великих міст концентрує у собі більшість екологічних проблем сучасної цивілізації. Погіршення якості джерел життєзабезпечення (води та повітря), деградація природного довкілля, засміченість, мікрокліматичні зміни - все це, зібране разом у місті, підвищує і без того високу напруженість міського життя. При цьому, саме на містянах лежить значна доля відповідальності за стан довкілля. Засміченість, загазованість міст, дефіцит енергоресурсів є результатом життєдіяльності пересічних громадян. Однак питання підвищення екологічності життєдіяльності людей, зокрема психологічні проблеми формування активної позиції щодо свого способу життя у місті, залишаються практично не вирішеними.

Переважаючий інтерес до вивчення об'єктивних чи суб' єктивних чинників формування способу життя розрізняє психологічний та соціологічний підходи до дослідження цього феномену. В соціології, у зв'язку із завданнями опису типового способу життя різних соціальних груп, спосіб життя розглядається як явище, обумовлене суспільно-економічними і політичними чинниками, які дещо заломлюються через систему індивідуальних цінностей та інтересів. Психологи наголошують на тому, що особистість включається в сукупність причин і наслідків свого життя не тільки як залежна від зовнішніх обставин, але й як така, що активно їх перетворює, більше того, як формуюча в певних межах позицію і лінію свого життя [4].

Механізм взаємодії суб'єктивних і об'єктивних чинників способу життя розкривається Ю. М. Швалбом [3, с. 150]. Він представляє об' єктивні чинники навколишнього середовища у вигляді набору змістів або функціональних місць, які потенційно можуть входити в спосіб життя. Наприклад, середовище міста можна описати набором функціональних місць 3 їх нормативно заданими елементами - місця проживання, праці, дозвілля, ритуально-символічні місця тощо. Таке середовище входить в спосіб життя особистості, шляхом вибору і освоєння нею певного функціонального місця, формування 3 нормативних компонентів місця психологічної структури діяльності — цілей, мотивів, операціонального складу, результату. Якщо у такій діяльності розвивається особистість, задовольняються та збагачуються її потреби, діяльність стає життєдіяльністю, компонентом способу життя. У цьому виявляється дія суб'єктивного чинника способу життя.

Досліджуючи на основі розглянутої моделі спосіб життя особистості, ми сконцентрувалися на питанні ставлення до середовища, функціональні місця якого входять в структуру життєдіяльності, в спосіб життя особистості. В яких психологічних характеристиках розкриваєть- 
ся таке ставлення, чи можна описати його в емоційно-дійових термінах близькості, спорідненості, турботи, захисту середовища? Відповідь на ці питання відкриває можливості пошуку шляхів формування екологічно відповідальної поведінки у самому бутті, у повсякденній життєдіяльності людини.

Мета статті полягає у встановленні особливостей способу життя міської родини як чинника ціннісного ставлення дітей до міського середовища.

Під способом життя родини ми розуміємо організацію видів ії життєдіяльності, у яких вона освоює навколишнє середовище для підтримки та забезпечення свого повсякденного життя. До видів життєдіяльності, що у своїй сукупності складають спосіб життя особистості чи спільноти, найчастіше відносять виробничу, освітню, побутову, дозвільну, культурну, оздоровчу, суспільну [3, с. 18-22]. Не треба, мабуть, доводити, що в сучасних умовах повсякденна життєдіяльність людей має набувати екологічного змісту. Такий зміст, на нашу думку, може бути органічним проявом активності особистості, спрямованої на освоєння змістів або функціональних місць середовища в спосіб, який сприяє задоволенню множини іiі фізичних, соціальних та духовних потреб. Завдяки гармонійній взаємодії людини із навколишнім середовищем воно може усвідомлюватися як особистісна цінність i на цій основі зберігатися та розвиватися.

Виходячи з результатів теоретичної розробки проблеми, були поставлені завдання емпіричного дослідження, а саме довести: 1. Що спосіб життя сучасної міської родини може бути екологічно орієнтованим; 2. Що екологічно орієнтований спосіб життя родини сприяє переживанню її членами, в тому числі і дітьми, середовища як продовження свого «Я», ідентифікації з ним i, як наслідок, дбайливого ставлення до нього. Для рішення першого завдання були виділені: а) два види життєдіяльності родини - побутова життєдіяльність та дозвілля, які родина найчастіше здійснює як груповий суб'єкт, тобто має єдність мети, спільні мотиви та певну координацію дій окремих своїх членів; б) функціональні місця міського середовища, що відповідають за своїм змістом здійсненню побутової життедіяльності родини та іiі дозвіллю. В якості таких місць досліджувалися квартира (рівень мікросередовища), природні, культурні, історичні центри міста (рівень макросередовища); в) прояви екологічно орієнтованого способу життя родини. В якості такого прояву у побутовій життєдіяльності, що здійснюється у мікросередовищі квартири, ми розглядаємо активність родини, спрямовану на облаштування особистого простору [1, с. 67-83] кожного іiі члена, в тому числі і дитини. В якості такого прояву у проведенні родинного дозвілля у макросередовищі міста може бути активність родини по освоєнню природного, культурного, історичного потенціалу міста: спільного відвідання природних зон, спортивних об'єктів, театрів, музеїв, культурних заходів тощо. Якщо будуть виявлені вказані прояви способу життя родини та встановлені зв'язки між ними, то можна стверджувати, що екологічно орієнтований спосіб життя є реально існуючим феноменом родинного буття.

Для вирішення другого завдання емпіричного дослідження треба було емпірично виділити прояви ціннісного ставлення дитини до міського середовища. В якості такого прояву були обрані акти ідентифікації дитини з міським мезосередовищем, зокрема, мікрорайоном ऑiі проживання. Важливо було з'ясувати, чи впливає екологічна орієнтація способу життя родини у мікро- та макросередовищах на ставлення дитини до мікросередовища, активність у якому спеціально не фіксується i, таким чином, не розглядається як окрема детермінанта ставлення. Якщо такий вплив буде виявлений, то можна вважати, що екологічна орієнтація способу життя родини $€$ важливим чинником ціннісного ставлення дитини до міського довкілля як такого.

Таким чином в якості незалежної змінної у дослідження виступають прояви способу життя родини (побутова життєдіяльність та дозвілля) у міському мікрота макросередовищах, залежною змінною 
виступають показники ціннісного ставлення та ідентифікації дитини 3 міським мезосередовищем, у якості якого обраний мікрорайон проживання дитини.

Методи дослідження: опитувальний метод, суб'єктивне шкалювання, вивчення продуктів діяльності. Методи статистичної обробки даних: кореляційний та факторний аналіз, встановлення достовірності розбіжностей середніх значень та процентів.

У відповідності з обраними методами, були розроблені оригінальні методики дослідження: анкетний опитувальник «Дозвілля родини у міському середовищі»; анкетний опитувальник «Особистий простір дитини у родинній оселі»; методика семантичного диференціалу «Мікрорайон проживання».

Вибірку дослідження склали 168 учнів 8-9 класів двох загальноосвітніх шкіл міста Києва.

Статистична обробка емпіричного матеріалу, зібраного у дослідженні, здійснювалася у кілька етапів. На першому етапі обраховувалися середні значення із суми індивідуальних показників, отриманих при обробці анкетних опитувальників «Дозвілля родини у міському середовищі» та «Особистий простір дитини у родинній оселі». На другому етапі вивчалися зв'язки між показниками екологічно орієнтованого способу життя родини у мікро- та макросередовищах, отриманими за допомогою зазначених вище анкетних опитувальників. Для цього був обрахований коефіціент рангової кореляції Спірмена між рядами індивідуальних показників по кожній анкеті. Він виявився значущим ( $\mathrm{r}=0,217$, при $\mathrm{p} \geq 0,05)$, що свідчить, певною мірою, про наявність загальної спрямованості на дотримання чи недотримання родиною екологічно орієнтованого способу життя у різних сферах життєдіяльності. Така загальна спрямованість наповнюється конкретним поведінковим змістом на різних рівнях міського середовища в залежності від їх специфічного устрою.

На третьому етапі 3 рангових рядів середніх значень індивідуальних показників за кожним анкетним опитувальником, шляхом обрахування показника напівінтерквартильного розмаху (Q), виділялися значення, що входять до першого та четвертого квартилей, тобто достовірно відрізняються за своєю величиною. Шляхом співставлення таких значень по кожному з двох анкетних опитувальників були виділені респонденти, які мали найнижчі (увійшли до I квартиля) та найвищі (увійшли до IV квартиля) показники за обома методиками. Таким чином були виділені групи підлітків, які за даними дослідження, мають суттєві відмінності у способі життя 3 точки зору його екологічної орієнтації. Всього було виявлено 38 осіб, які характеризують спосіб життя своєї родини як екологічно орієнтований і 37 осіб, які не вказують на ознаки екологічної орієнтації у способі життя своєї родини.

На останньому четвертому етапі за шкалами методики семантичного диференціалу «Мікрорайон проживання», вивчалася структура уявлень про своє міське мезосередовище підлітків, які є членами родин 3 наявністю та відсутністю у способі життя екологічної орієнтації. Результати факторного аналізу (методом головних компонент iз застосуванням Varimax-ротаціï) шкал семантичного диференціалу у кожній 3 двох груп підлітків свідчать про суттєві розбіжності в структурній організації уявлень підлітків про мікрорайон проживання.

В групі з вираженою екологічною орієнтацією способу життя родини виділилися три змістовних фактори, що охоплюють 55 \% загальної дисперсії. Перший фактор, інформативністю 38 \%, є оціночним за критерієм задоволення у мікрорайоні тих чи інших потреб підлітка. До нього увійшла шкала «Один 3 найкращих районів - один 3 найгірших районів» $(\mathrm{r}=0,802)$ разом iз шкалами: «В районі багато друзів - немає друзів» $(\mathrm{r}=0,676)$, «Гарне транспортне сполучення - погане транспортне сполучення» $(\mathrm{r}=0,807)$, «Багато магазинів та супермаркетів - мало магазинів і супермаркетів» $(\mathrm{r}=0,828)$. Цей фактор отримав назву «Загальна оцінка мікрорайону в зв'язку із задоволенням у ньому індивідуальних потреб». 
Другий фактор, інформативністю 13\%, характеризує прагнення підлітків пишатися своїм районом проживання у зв'язку 3 його оцінкою. До цього фактору увійшла шкала «С чим пишатися в районі - немає чим пишатися» $(\mathrm{r}=0,676)$, пов'язана 3 такими шкалами як «Веселий - сумний» $(\mathrm{r}=0,845)$, «Хороший - поганий» $(\mathrm{r}=0,727)$, «Багато спортивних центрів - відсутні спортивні центри» $(\mathrm{r}=0,746)$. Цей фактор отримав назву «Переживання гордості за мікрорайон у зв'язку з його оцінкою».

Третій фактор, інформативністю 12\%, характеризує сприймання стану екології у мікрорайоні у зв'язку з елітністю його забудови. До цього фактору увійшла шкали «Чистий - брудний» $(\mathrm{r}=0,830)$, «Багато зелених насаджень - відсутні зелені насадження» $(\mathrm{r}=0,761)$ у зв'язку із шкалою «Елітна забудова - низький клас забудови» $(\mathrm{r}=0,765)$. Така конфігурація шкал $\epsilon$ свідченням репрезентації у свідомості певних чинників екологічного стану місця проживання. Цей фактор отримав назву «Оцінка екології в мікрорайоні у зв'язку 3 елітністю його забудови».

В групі підлітків з відсутністю екологічної орієнтації у способі життя родини виділилися два змістовних фактори, що охоплюють 52,9\% дисперсії.

Перший фактор, інформативністю $38 \%$, так саме, як у попередній групі підлітків, $\epsilon$ оціночним, оскільки до нього теж увійшла шкала «Один з найкращих районів - один 3 найгірших районів» $(\mathrm{r}=0,675)$. Однак ця шкала корелює з іншим набором шкал, ніж у попередньому випадку. Це шкали: «Престижний - непрестижний мікрорайон» $(\mathrm{r}=0,869)$; «Елітна забудова — низький клас забудови» $(\mathrm{r}=0,642)$; «Багато спортивних центрів - відсутні спортивні центри» $(\mathrm{r}=0,726)$; «Великий район — маленький район» $(\mathrm{r}=0,733)$. Таким чином, цей фактор включає описові шкали (розмір району, наявність спортивних споруд) разом з характеристиками елітності, престижності, які відображають не стільки індивідуальні потреби підлітка, скільки запозичені у дорослих еталони сприймання місця проживан- ня. В цілому цей фактор, на нашу думку, характеризує дещо відчужену, не пов'язану 3 власними потребами, позицію підлітка щодо мікрорайону. Цей фактор отримав назву «Загальна оцінка мікрорайону у зв’ язку 3 його розмірами та престижністю».

До другого фактору, який має інформативність $14 \%$, увійшли шкали, які репрезентують сприймання екологічного стану мікрорайону — «Чисте повітря - екологічно забруднене повітря» $(\mathrm{r}=0,642)$; «Чисті водоймища - брудні водоймища» $(\mathrm{r}=0,814)$ разом із шкалами, які відображують певну безпеку проживання у ньому: «Затишний — шумний» $(\mathrm{r}=0,844)$; «Безпечний - небезпечний» $(\mathrm{r}=0,559)$; «Добрі люди - злі люди» $(\mathrm{r}=0,857)$. Цей фактор отримав назву «Оцінка безпеки в мікрорайоні».

Проведемо порівняльний аналіз факторних структур уявлень про мікрорайон проживання у двох групах. Перша відмінність полягає у тому, що у підлітків — членів родин з високим рівнем екологічної орієнтації способу життя, образ району більш диференційований. Про це свідчить наявність тривимірної категоріальної модели сприймання мікрорайону (три фактори, з інформативністю кожного більше $10 \%$, описують $55 \%$ сумарної дисперсії) проти двовимірної у підлітків — членів родин з відсутністю екологічної орієнтації способу життя (два фактори, з інформативністю кожного більше $10 \%$, описують $53 \%$ сумарної дисперсії). Отже, підлітки першої групи мають більш широку систему категорій для оцінки свого міського мезосередовища.

Друга відмінність полягає у змісті факторів. Перший фактор, який є фактором загальної оцінки мікрорайону, має різне змістовне наповнення такої оцінки. В групі 3 високим рівнем екологічної оріснтації способу життя оцінка пов'язана із можливістю задоволення в мікрорайоні індивідуальних потреб підлітків, в групі з низьким рівнем такої орієнтації оцінка пов'язана 3 характеристиками мікрорайону, відстороненими від підліткових потреб - його престижністю та розмірами. Дуже цікавими виглядають відмінності у змісті другого фактору. В групі з високим рівнем екологічної орієнтації 
способу життя це фактор - «Переживання гордості за мікрорайон у зв'язку з його оцінкою». Присутність почуття гордості в системі суб'єктивних оцінок свого середовища певною мірою свідчить про прагнення підлітка включити мікрорайон в систему уявлень про себе, ідентифікуватися з ним. В групі з низьким рівнем екологічної орієнтації способу життя це фактор - «Оцінка безпеки в мікрорайоні». На нашу думку, наявність категорії «безпечність - небезпечність» у свідомості цієї групи підлітків, та усвідомлення мікрорайону проживання крізь іï призму, пов'язане з відсутністю суверенності підлітка в житловому мікросередовищі. Тут, в силу неможливості контролювати свою територію проживання, він постійно наражається на небезпеку бути викритим, не має можливості зберегти недоторканими власні речі тощо.

Важливо зазначити, що у свідомості обох груп підлітків представлений екологічний стан мікрорайону проживання. Однак, якщо в свідомості підлітків групи 3 високим рівнем екологічної орієнтації способу життя, екологія району є репрезентованою у зв'язку з його об'єктивною характеристикою - елітністю, якістю його забудови, то у групі з відсутністю такої орієнтації вона лише емоційно забарвлена як фактор небезпеки, без ознак роздумів про походження такої небезпеки.

Ми зпівставили систему категорій, на яких, за результатами ФА, базується сприймання мікрорайону проживання підлітками з сімей, що демонструють екологічно орієнтований спосіб життя, 3 даними отриманими у дослідженні англійських психологів Д. Юззела і С. Твіггер-Росса [7]. Це дослідження стосувалося проблеми ідентифікації з районом проживання на прикладі жителів Доков (Docklands), житлового мікрорайону в Лондоні. Виходячи 3 концепції структури ідентичності Г. Брейквелл [6], автори виділили такі показники територіальної ідентичності: 1) безперервність (continuity). Цей показник означає відповідність середовища перебування потребам та бажанням індивіда, а також бажання зберегти місце прожи- вання, оскільки з ним були пов'язані значимі події; 2) самооцінка - складається із гордості за своє місце проживання, його статусу у суспільства, радості перебування у ньому, а також задоволеності фізичними якостями цього місця; 3) самоефективність - як оцінка місця проживання з точки зору екології, забрудення, розвитку інфраструктури, рівня злочинності; 4) відмінності — як оцінка місця проживання в цілому, ідентифікація з ним.

Порівняльний аналіз вказаних показників із категоріями сприймання, емпірично виділеними у нашому дослідженні, продемонстрував високу ступінь їх збігу. Підлітки із сімей з екологічно орієнтованим способом життя сприймають мікрорайон проживання на основі того чи задовольняє він їх потреби, чи можуть вони ним пишатися, чи благополучний він 3 точки зору екології. Наявність у свідомості саме таких критеріїв сприймання виступає підставою для ідентифікації з місцем проживання, включення його в систему уявлень про себе. Така ідентифікація з територіями життєдіяльності є важливою внутрішньою умовою формування дбайливого ставлення до них.

В цілому за результатами дослідження можна зробити наступні висновки.

У вирішенні екологічних проблем міста значну роль відіграє активність жителів, 3окрема, їх активна позиція щодо свого способу життя у місті. Така позиція змістовно розкривається в екологічно орієнтованому способі життя особистості та групи.

Емпірично виявлені прояви екологічно орієнтованого способу життя міської родини, які полягають у наявності в її життедіяльності активності, спрямованої на освоєння міських умов життя в спосіб, який сприяє задоволенню множини фізичних, соціальних та духовних потреб всіх членів родини, в тому числі і підростаючого покоління.

Доведено, що екологічно орієнтований спосіб життя родини сприяє усвідомленню підлітками — членами родини цінності, значущості умов міського довкілля для свого існування та розвитку і переживанню його на цій основі як продовження 
свого «Я», ідентифікації з ним і, як наслідок, готовності дбати про нього.

Перспективи подальших розробок полягають у вивченні поведінкової складової готовності до ідентифікації з міськими територіями як реального прояву активності із їх збереження та розвитку.

\section{Список використаних джерел:}

1. Нартова-Бочавер С.К. Человек суверенный: психологическое исследование субъекта в его бытии / С. К. Нартова-Бочавер. - СПб. : Питер, 2008. - 400 с.

2. Орлова Э. А. Социокультурное пространство обыденной жизни : методическое пособие по курсу «Культурная антропология» / Є. А. Орлова. — М., 2002. — 104 с.

3. Швалб Ю.М. Образ жизни и качество жизни как экопсихологические проблемы / Ю.М. Швалб // Экопсихологические исследования : сборник материалов 5-й Российской конференции по экологической психологии. - М. : Психологический институт РАО, 2009. - C. 148-161.

4. Ядов В.А. Взаимосвязь социологического и социально-психологического подходов к исследованию образа жизни / В.А. Ядов // Психология личности и образ жизни. - М. : Наука, 1987. - С. 89-92.

5. Altman I. The Environment and Social Behavior: Privacy, Personal space / I. Altman. — Brooks Cole, Monterey, CA, 1975. - P. 93-146.

6. Breakwell G. M. Identity / G.M. Breakwell. - Thousand Oaks — New Delhi, 2003. P. 57-63.

7. Twigger-Ross C. L. Place and Identity Processes / C.L. Twigger-Ross, D. Uzzell // Journal of Environmental Psychology. — 1996. - Vol. 16. Iss. 3. - P. 205-220.

Аннотация. В статье представлены результаты эмпирического исследования влияния экологически ориентированного образа жизни городской семьи на отнотение подрост-

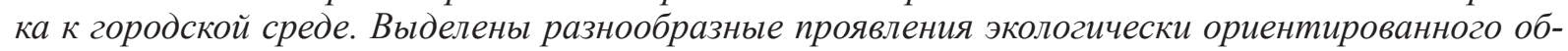
раза жизни семьи в микро- и макросреде города. Эти проявления объединяет направленность семейной жизнедеятельности на полноченное освоение городских условий жизни, удовлетворение в городской среде всех групп потребностей личности: физических, соииальных, духовныхх. Доказано, что экологически ориентированный образ жизни семьи способствует формированию иенностного отношения подростка к городу и идентификаиии с ним.

Ключевые слова: образ жизни, экология города, психология жизнедеятельности, территориальная идентичность.

Abstracts. The article deals with the results of an empirical study of the effect of ecologically concerned lifestyle of urban families on the teenager's attitude to the urban environment. Various manifestations of environmentally oriented lifestyle of the family in the micro and macro environment of the city are highlighted. Unifying feature of these manifestations is that family life is focused on full mastering of urban living conditions to satisfy all groups of needs of the individual in the urban environment (physical, social, spiritual). It is proved that environmentally oriented lifestyle of the family contributes to the formation of the valuable relation to the city and the teenager's identification with it.

Keywords: lifestyle, ecology of a city, psychology of lifestyle, territorial identity. 